\title{
VOTING RIGHTS LITIGATION AND \\ THE ARKANSAS JUDICIARY: \\ GETTING WHAT YOU DIDN'T ASK FOR
}

\author{
James D. Gingerich \\ (Director, Administrative Office of the Courts, \\ Supreme Court of Arkansas)
}

\section{Introduction}

Many authors and researchers have commented about the role of courts, both federal and state, as public policy makers (Dahl, 1958; Grossman and Wells, 1966 and 1980; Shubert, 1974; Horowitz, 1977; Jacob, 1983). Others have studied the process of implementing judicial decisions and their effect upon public policy and other political institutions (Wasby, 1970; Baum, 1976, 1977, and 1985; Tarr, 1977; Johnson and Canon, 1984). Public policy analysts have shown that the longrecognized uncertainties in public policy-making frequently result in unintended consequences (Lindblom, 1968). Such unintended results are even more likely in the judicial decision-making setting, given the questioned authority and ability of courts to make policy, the lack of sufficient enforcement mechanisms, and the diverse nature of the implementing populations (Johnson and Canon, 1984).

In Arkansas, a prime example of unintended consequences of judicial decision-making could result from the clash over the state's method of selecting members of the judiciary. On July 27, 1989, Arkansas joined eight other states whose methods of selecting judges is being challenged as violating the federal Voting Rights Act. In each state minority voters allege that the method of selecting judges (either partisan or non-partisan elections) dilutes their ability to select judges of their choice. The remedy most often sought by plaintiffs is a re-drawing of district lines in such a way as to maximize the concentration of black voters in each district. An unanticipated result, however, may be to lend support to the judicial reform movement active in many states - including Arkansas - resulting in a change from an elective system for judges to some form of merit selection.

The purpose of this article is to outline Arkansas' history of selecting judges, describe the nature of the litigation and its outcome in other states, 
and assess the possible consequences for Arkansas' method of judicial selection.

\section{Arkansas' History of Judicial Selection}

The history of judicial selection in Arkansas is very similar to that of the country as a whole. Various methods have been considered, adopted, and then abandoned, dependent upon the political philosophy of the time.

In the formative years of government both under the Articles of Confederation and the early years of the U.S. Constitution, two methods of state judicial selection were favored - election by the legislature or appointment by the Governor with confirmation by the legislature (Dubois, 1980). Until 1845, all new states entering the Union adopted one or the other of these methods. Arkansas has utilized both. Under the original Constitution of 1836 , both trial and appellate judges were selected by a majority vote of both houses of the General Assembly (Ark. Const. of 1836, Art. IV, Sect. 7). County judges were selected by a majority vote of the justices of the peace of each county, who were themselves selected by the voters in each township (Ark. Const. of 1836, Art. VI, Sect. 10,15). In 1848 , the Constitution was amended to provide for direct election of circuit and county judges, with appellate judges remaining subject to election by the legislature (Ratified Nov. 24, 1848). Under the Civil War Constitution, voters continued to elect county and circuit judges, but judges of the Supreme Court were appointed by the Governor with confirmation by the Senate (Ark. Const. of 1861, Art. VI, Sect. 7, 8, 12, 16). With the adoption of the 1864 Constitution, all judges were selected by direct election (Ark. Const. of 1864, Art. VII, Sect. 7, 8, 12, 18); however, this was short-lived as the Constitution of 1868 provided for gubernatorial appointment of the Chief Justice and all inferior court judges and direct election of the four associate justices of the Supreme Court (Ark. Const. of 1868, Art. VII, Sects. 3, 5).

This general trend of a greater utilization of elections and more direct participation in selection by voters was representative of what was occurring on the national level. The advent of "Jacksonian democracy" included a call to the end of an "elitist judiciary" and a return of the power of selection to the people. Mississippi became the first state to provide for a completely elected judiciary in 1832. From the admission of Iowa in 1846 to the admission of Arizona in 1912, every state provided for an elected judiciary (Dubois, 1980). 
Arkansas' present constitution, adopted in 1874, provides for direct election of all its judges (Ark. Const. of 1874, Art. 7, Sects. 6, 13, 29, 38). As of January 1,1990, there are seven Supreme Court justices who run in statewide elections for an eight year term, six Court of Appeals judges who run in one of six districts for an eight year term, thirty-four circuit judges and twenty-seven circuit/chancery judges who run in one of twenty-four districts for a four year term, and thirty-three chancery judges who run in one of twenty-four districts for a six year term. All trial and appellate judges run in partisan elections. Voters of the state also elect judges to 124 municipal courts, 75 county courts, 13 courts of common pleas, 93 city courts, and 5 police courts.

Nationwide, over one-third of the states provide for partisan or nonpartisan election of their trial and/or appellate judges, one-third provide for selection by the Missouri plan or a modified Missouri plan, and the remaining opt for some form of gubernatorial appointment or legislative election (National Center for State Courts, 1988). (See Tables 1 and 2.)

\section{The Voting Rights Act of 1965}

The Voting Rights Act was enacted in 1965 as one of a series of pieces of civil rights legislation designed to remedy a history of racial discrimination in state elections (42 U.S.C., Sec. 1973). The Act was amended in 1975 and 1982 to extend the provisions to other minority groups and the disabled. The main provision of the act is found in Section 2 which provides:

(a) No voting qualification or prerequisite to voting or standard, practice, or procedure shall be imposed or applied by any state or political subdivision in a manner which results in a denial or abridgement of the right of any citizen of the United States to vote on account of race or color, or in contravention of the guarantees set forth in section 1973(f) 2 of this title, as provided in subsection (b) of this section.

(b) A violation of subsection (a) of this section is established if, based on the totality of circumstances, it is shown that the political processes leading to nomination or election in the state or political subdivision are not equally open to participation by members of a class of citizens protected by subsection (a) of this section in that its members have less opportunity than other members of the electorate to participate in the political process and to elect representatives of their choice. The extent to which members of a protected class have been elected to office in the state or political subdivision is one circumstance which may be considered: Provided, that nothing in this section establishes a right to have members of a protected class elected in numbers equal to their proportion in the population. 
The essence of a claim under the act is that a certain election law or practice combines with social or historical conditions to cause an inequality in the opportunities of minority voters to elect candidates of their choice. A showing of an intent by the state or its officers to discriminate is not a necessary component of a successful claim. If the plaintiffs can show that the effect of a law or election system is to dilute the voting strength of the minority group, a remedy may be available. Most of the claims which have been asserted have involved systems which utilized multi-member districts and at- large voting schemes. The U.S. Supreme Court has suggested that in these cases plaintiffs must meet three basic tests. First, the minority group must demonstrate that it is sufficiently large and geographically compact to constitute a majority in a single member district. If the group is so small that no district could be formed in which the minority voters could potentially elect their candidate, then the multi-member structure is not detrimental. Second, the minority group must be able to show that it is politically cohesive. Third, the minority must be able to demonstrate that the white majority votes sufficiently as a block to enable it, in the absence of special circumstances, usually to defeat the minority preferred candidate (Thornburg v. Gingles, 478 U.S. 30 [1986]).

The Act has been used in hundreds of lawsuits nationwide to challenge state and local election systems. Most of the early challenges involved local city council and school board elections and other minor positions. Later, statewide positions were also challenged. Until 1985, all of the cases involved challenges to legislative or executive positions. That year in Mississippi, a lawsuit was filed contesting the method used to select county judges in three Mississippi counties, and all circuit and chancery judges in the state elected from multi-member districts. In 1987, the U.S. District Court for the Southern District of Mississippi held that judicial elections are no different than any other type of elections for the purpose of the application of the Voting Rights Act (Martin v. Allain, 658 F. Supp. 1183 [S.D. Miss. 1987]).

\section{Are Judicial Elections Different?}

The argument that judicial elections are somehow different from other elections and thus exempt from the application of the Voting Rights Act is centered around three major points. The first is based upon the language of the act itself. Subsection (b) of section 2 provides that a minority group must have a lesser opportunity to elect "representatives" of its choice. Are judges "representatives" of voters in the same way as 
mayors or legislators? In several cases it has been argued that Congress' use of the word "representative" indicated an intent to distinguish judicial positions. In Mallory vs. Eyrich (839 F. 2d 275 [6th Cir. 1988]), the court stated:

There is a conceptual difference between the role of legislatures and executives and the role of judges. Both legislatures and executives are intended under the Constitution of the United States and the Constitution of Ohio to be "representative." The power to legislate and the power to administer should only be performed in accordance with the wishes of the populous. At stated times, the actions of legislators and the executives are reviewed and franchised members of society make a new selection. . . . Legislators and judges simply perform different functions. ..

To refer to a "partisan legislator" may be a mark of approval; to refer to a "partisan judge" is a mark of condemnation and one which removes him completely from the role of an unbiased arbiter of societal conflicts.

Other courts have noted the distinction which the U.S. Constitution makes in the treatment of the legislative and executive branch on the one hand, and the judicial branch on the other. In fact, the writings of Alexander Hamilton in the Federalist, No. 78, have been quoted by more than one court for the proposition that judges were intended to be treated differently.

If it be said that the legislative body are themselves the constitutional judges of their own powers and that the construction they put upon them is conclusive upon the other departments, it may be answered that this cannot be the natural presumption where it is not to be collected from any particular provisions in the Constitution. It is not, otherwise, to be supposed that the Constitution could intend to enable the representatives of the people to substitute their will to that of their constituents. It is far more rational to suppose that the courts were designed to be an intermediate body between the people and the legislature in order, among other things, to keep the latter within the limits assigned to their authority. The interpretation of the laws is the proper and peculiar province of the courts.

The second argument relates to the management and administration of judicial systems. Judicial districts in most states were not created based upon the population of a particular area as are legislative districts. Most often it is the number of cases filed in a particular area which drives the need for a new judge or a new judicial district. The current assessment method utilized by the Arkansas Judicial Council for recommending new judgeships or judicial districts includes such factors as the number of cases filed, the number of cases disposed of, the size of the circuit, the number of 
courthouses, the number of lawyers in the circuit, and the size of the support staff available in each county. The population of the circuit is not utilized at all. Thus, the "one man, one vote" principles which are existent in legislative district cases are not applicable in judicial cases.

Finally, the nature and philosophy of judicial elections is vastly different from other kinds of elections. The Code of Judicial Conduct places strict limits on the methods of financing and conducting judicial campaigns. Canon 7B (1)(c) of the Code provides that a judge or a candidate for a judgeship should not make any pledges or promises as to conduct in office or announce his views on any disputed legal or political issue. These limitations make almost impossible the ability of voters to choose a judge to "represent" them since the judge is always prohibited from sharing with voters his or her positions on any issues. This is, no doubt, one of the reasons that all of the evidence indicates that judicial elections produce the lowest amount of knowledge by voters about the candidates and the lowest voter turnout of any other type of election (Dubois, 1979).

The Code of Judicial Conduct also limits the ability of judicial candidates to publicize even generic information about themselves in that campaign contributions may never be solicited by the individual candidate and the candidate's committee may only accept contributions within 180 days of the election. These provisions have both the intent and effect of limiting the amount of money spent in a judicial election. A recent study showed that the average amount spent in an Arkansas judicial election between 1976 and 1988 was $\$ 14,826$, well below the average amount spent in legislative or executive races (Gingerich, 1989).

Despite all of these arguments, federal trial or appellate courts in Mississippi, Louisiana, Illinois, and Ohio have ruled that judicial elections are not distinct and are subject to the provisions of the Voting Rights Act. The issue is currently pending in federal courts in Texas, Alabama, Florida, Georgia, and Arkansas.

\section{The Arkansas Case}

The Arkansas lawsuit, Hunt v. Arkansas (PB-C-89-406), was filed on July 27, 1989 in the Pine Bluff Division of the U.S. District Court for the Eastern District of Arkansas. Plaintiffs include several black attorneys, a black civic leader, and the Christian Ministerial Alliance. Defendants include the Governor, other constitutional officers of the state, and the chairmen of the Arkansas House and Senate Judiciary Committees. 
Plaintiffs originally challenged the systems utilized for the election of all of the state's appellate and general jurisdiction judges. The complaint was subsequently amended to contest only the general jurisdiction judges who reside in one of seven districts in central and eastern Arkansas. Presently, Arkansas has 24 judicial circuits from which are elected 97 circuit and chancery judges (see Figure 1 at end). The seven circuits under attack range in size from one county to six counties. Two of the circuits are served by only one judge, and one circuit has as many as 16 judges. In those circuits with more than one judge, plaintiffs allege that the circuitwide, staggered-term, numbered-place elections dilute minority voting strength. In addition, they allege that the boundary lines for the circuits were drawn in such a way as to fragment the concentration of black voters.

Two specific remedies are sought. Either the current district lines should be re-drawn to create majority-black, single-member districts or an alternative voting system should be employed. Specifically, plaintiffs ask the court to order the use of "limited or cumulative voting." Limited voting allows each voter to vote for only one or two of the positions which would all be contested at the same time. Cumulative voting would give to each voter several votes which he or she could cast for one candidate or allocate between two or more candidates. Both types of voting enhance the vote of minority citizens, assuming they support the same candidate or candidates.

The defendants filed their initial response to the lawsuit on October 10, 1989. They seek dismissal of the lawsuit on the basis that judicial elections are not intended to be covered by the Voting Rights Act. In the event that the court finds that such elections are covered, they also make several alternative arguments. They allege that the plaintiffs have failed to prove one of the pre-conditions for a Voting Rights Act lawsuit - that the "minority group is large and geographically compact to constitute a majority in a single member district." Defendants introduced population data which shows that black citizens constitute a majority in only 3 Arkansas counties and argue, therefor, that no districts can be created which have a majority black population. A trial date has been set for June, 1991.

\section{The Problem With Implementation: How To Get What You Didn't Ask For}

If plaintiffs are successful in showing that the Arkansas judicial election system violates the Voting Rights Act, what is the likely result? 
What remedies might the court consider in response? The experiences of other states which have completed litigation do not provide much guidance.

North Carolina and Mississippi both settled their litigation out of court and, thus, did not create a need for any court- mandated remedy. In North Carolina, the General Assembly created nine majority black judicial voting districts and eliminated staggered term elections, which proved acceptable to the plaintiffs. In Mississippi, single-member, sub-election districts were created from the previous multi-member districts and post requirements (designated seats) in some multi-member districts were eliminated. In addition, no sub-district residency requirement was adopted, so that candidates are able to run from any sub-district within the original district.

In Louisiana, the Governor appointed a 31-member task force on judicial selection to devise a remedy to the litigation. The task force made several recommendations to the Louisiana legislature, including the scraping of the election system in favor of merit selection and the creation of sub-election districts. The legislature opted for the creation of subelection districts within the existing judicial districts, some of which are predominantly black. Once elected from the sub-district, the judge will serve the entire district. The existing judicial posts or positions were maintained, each being assigned to a specific sub-district. Candidates must reside within the judicial district but not within the particular subdistrict. The legislature also referred proposed constitutional changes to the voters, including the creation of senior status judges and a merit system plan for the gubernatorial appointment of interim judicial vacancies. In response to a second Louisiana lawsuit contesting Supreme Court districts, the legislature split one of the districts to allow for the creation of one black majority district (Haydel, 1989).

One of two voting rights lawsuits has been decided in Texas with the court finding a violation of the act, but no remedies have as yet been considered by the court. A recommendation has been made to the Texas legislature that elections in appellate races be discarded and a merit system substituted. No action, however, has been taken (Cooke, 1989).

There is, therefore, no consistent implementation of any particular remedy. The most prevalent remedy seems to be the division of large districts into sub-districts for the purpose of election or the complete redrawing of district boundaries. There are at least two possible problems with the use of this remedy in Arkansas. First, Arkansas is one of only 
three states in the Union which maintains separate trial courts of law and equity. There are currently an equal number of districts in the state but an unequal number of circuit (law) and chancery (equity) judges within each district. Current districts cannot, therefore, merely be divided into subdistricts. If the current number of judges is maintained, separate circuit and chancery sub-districts would have to be created. Depending upon the number of counties within the circuit, such divisions could create an administrative nightmare.

Second, there are simply not a sufficient number of areas within the state with both a substantial black population and a substantial caseload to allow for the creation of a black-majority district. Only three counties in the state have a black-majority population: Phillips, Lee, and Chicot. The total 1988-89 circuit caseload in each of these counties was 752, 231, and 422 respectively, and the chancery caseload was 708, 235, and 243 respectively. The average caseload for an Arkansas judge in 1988-89 was over 1,400 cases. In order to create a district with sufficient caseload, counties with greater white population have to be added, which then dilutes the black vote.

Limited and cumulative voting have been sought as a possible remedy, but no state has implemented such a remedy. Such voting systems have been voluntarily adopted by some local governments and have been used as a remedy in some local government voting rights cases. Because of the substantial change that they bring to a state's election system and the administrative problem of using one type of voting for one election and traditional voting for another election, it is unlikely that a federal court would, at least in the first instance, adopt such a remedy.

The final remedy which has been considered and/or adopted in other states is a move from an elective system to a merit plan system. This is usually not an option which is favored by black plaintiffs since it is perceived as further decreasing the possibility of black voters having the ability to directly choose a black judge. One plaintiff's lawyer has said "there is something rather sinister about taking away the power to vote for judges at the very time litigation under the Voting Rights Act promises that minority citizens will finally have their fair share of that power" (McDuff, 1989). Some have even suggested that such a move itself violates the Voting Rights Act. Nonetheless, because of the political and administrative problems inherent in the alternative remedies and the existence of a whole contingent of reformers who favor the imposition of a merit selection system under any circumstances, it may become the most likely result. 
Since the advent of the Missouri Plan, there has been an incessant debate over the advantages and disadvantages of elective and appointed systems (Watson and Downing, 1969; Jacob, 1968; Carson, 1972; Rosenberg, 1966; Dubois, 1980). Arkansas recently considered the issue when in 1985, the House of Delegates of the Arkansas Bar Association adopted a resolution calling for a constitutional amendment to abolish elections for Arkansas appellate judges. The resolutions were introduced in a somewhat altered form in both the House and Senate of the 1989 General Assembly, but neither was adopted. The debate will, no doubt, continue as the Arkansas Bar Association has appointed a Judicial Article Task Force to propose to the bar and the 1991 session of the General Assembly a new judicial article for the Arkansas Constitution which will include provisions concerning the method for selecting all judges. The combination of this vocal lobby in favor of merit selection and barriers to the implementation of other remedies may very well result in the unintended consequence of the abandonment of judicial elections.

It would indeed be "the irony of ironies" if a group of black lawyers is able to utilize a federal statute to achieve in a few short months a result which they do not particularly want, and which a crowd of judicial reformers has sought but been unable to achieve during fifty years of battling. And then there is the final irony - once again it is possible that a major state public policy decision will be made not in the traditional arena of the state capitol but rather in a federal court. 
Table 1. METHODS OF SELECTING STATE JUDGES

APPELLATE JUDGES

\begin{tabular}{|c|c|c|c|c|c|c|c|}
\hline $\begin{array}{l}\text { Partisan } \\
\text { Election } \\
\end{array}$ & $\begin{array}{l}\text { Nonpartisan } \\
\text { Election } \\
\end{array}$ & Merit Plan & $\begin{array}{c}\text { Gubernatorial } \\
\text { Selection }\end{array}$ & $\begin{array}{l}\text { Governor Appoints/ } \\
\text { RetentionElection }\end{array}$ & $\begin{array}{l}\text { Modified } \\
\text { Merit Plan } \\
\end{array}$ & $\begin{array}{l}\text { PartisarElection/ } \\
\text { Retention Election }\end{array}$ & $\begin{array}{c}\text { Legislative } \\
\text { Election or Appt. }\end{array}$ \\
\hline Alabama & Georgia & Alaska & Maine & \multirow[t]{14}{*}{ California } & Delaware & Illinois & Rhode Island \\
\hline Arkansas & Idaho & Arizona & New Hampshire & & Hawaii & Pennsylvania & Virginia \\
\hline Mississippi & Kentucky & Colorado & New Jersey & & Massachusetts & & South Carolina \\
\hline New Mexico & Louisiana & Florida & & & New York & & \multirow[t]{11}{*}{ Connecticut } \\
\hline Tennessee & Michigan & Indiana & & & Vermont & & \\
\hline Texas & Minnesota & Iowa & & & & & \\
\hline \multirow[t]{8}{*}{ West Virginia } & Montana & Kansas & & & & & \\
\hline & Nevada & Maryland & & & & & \\
\hline & No. Carolina & Missouri & & & & & \\
\hline & North Dakota & Nebraska & & & & & \\
\hline & Ohio & Oklahoma & & & & & \\
\hline & Oregon & South Dakota & & & & & \\
\hline & Washington & Utah & & & & & \\
\hline & Wisconsin & Wyoming & & & & & \\
\hline
\end{tabular}


Table 2. METHODS OF SELECTING STATE JUDGES

\begin{tabular}{|c|c|c|c|c|c|c|c|}
\hline \multirow[b]{2}{*}{$\begin{array}{l}\text { Partisan } \\
\text { Election }\end{array}$} & \multirow[b]{2}{*}{$\begin{array}{l}\text { Nonpartisan } \\
\text { Election }\end{array}$} & \multicolumn{4}{|c|}{ TRIAL JUDGES } & \multirow{2}{*}{$\begin{array}{l}\text { Merit Plan/ } \\
\text { No Retention } \\
\text { Election }\end{array}$} & \multirow{2}{*}{$\begin{array}{l}\text { Nonpartisan } \\
\text { Election/ } \\
\text { Retention Election }\end{array}$} \\
\hline & & Merit Plan & $\begin{array}{l}\text { Gubernatorial } \\
\text { Selection }\end{array}$ & $\begin{array}{l}\text { Partisan Election/ } \\
\text { Retention Election }\end{array}$ & $\begin{array}{l}\text { Legislative } \\
\text { Election or Appt. }\end{array}$ & & \\
\hline Alabama & Florida & Alaska & Maine & Illinois & South Carolina & Connecticut & California \\
\hline Arizona & Georgia & Arizona & New Hampshire & Indiana & Virginia & Delaware & \\
\hline Arkansas & Idaho & Colorado & New Jersey & Pennsylvania & & Hawaii & \\
\hline Kansas & Kentucky & Iowa & Rhode Island & & & Massachusetts & \\
\hline Mississippi & Louisiana & Kansas & & & & Vermont & \\
\hline Missouri & Michigan & Maryland & & & & & \\
\hline New Mexico & Minnesota & Missouri & & & & & \\
\hline New York & Montana & Nebraska & & & & & \\
\hline North Carolina & Nevada & Utah & & & & & \\
\hline Tennessee & North Dakota & Wyoming & & & & & \\
\hline Texas & Ohio & & & & & & \\
\hline West Virginia & Oklahoma & & & & & & \\
\hline & Oregon & & & & & & \\
\hline & South Dakota & & & & & & \\
\hline & Washington & & & & & & \\
\hline & Wisconsin & & & & & & \\
\hline
\end{tabular}




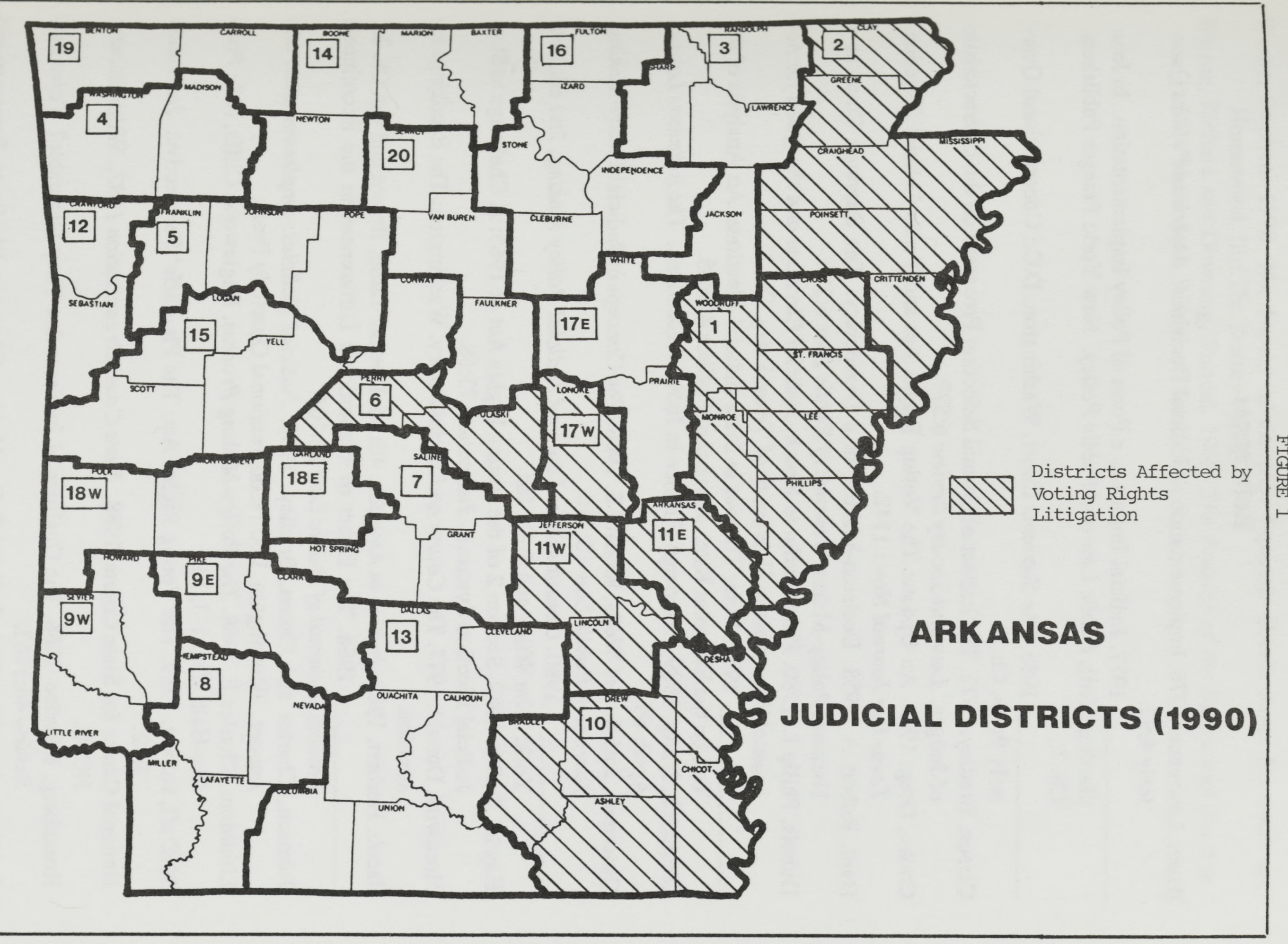




\section{References}

Baum, Lawrence. 1976. Implementation of Judicial Decisions. American Politics Quarterly 4:92.

1977. Judicial Impact as a Form of Policy Implementation. In John Gardiner (ed), Public Law and Public Policy. New York: Praeger Publishers. Ch. 7. terly Press. Ch. 6.

Carson, Bradley. 1972. The Impact of Formal Selection Processes on the Characteristic of Judges. Law and Society Review 6:579.

Cooke, Greg. 1989. An Update: The Voting Rights Act and Texas Judicial Selection. Texas Bar Journal Nov.: 1142.

Dahl, Robert A. 1958. Decision-Making in a Democracy: The Supreme Court as a National Policy-Maker. Journal of Public Law 6:286.

Dubois, Philip L. 1980. From Ballot to Bench: Judicial Elections and the Quest for Accountability. Austin: University of Texas Press. Ch. 1.

1979. Voter Turnout in State Judicial Elections: An Analysis of the Tail on the Electoral Kite. Journal of Politics 41:865.

Gingerich, James. 1989. Campaign Finance in Judicial Elections. The Arkansas Lawyer April: 66.

Grossman, Joel B. and Wells, Richard S. 1966. The Concept of Judicial Policy-Making. Journal of Public Law 15:286.

1980. Constitutional Law and Judicial Policy Making, 2nd ed. New York: John Wiley and Sons, Inc.

Haydel, Judith. 1989. Section 2 of the Voting Rights Act of 1965: A Challenge to State Judicial Election Systems. Judicature 73:68.

Horowitz, Donald. 1977. The Courts and Social Policy. Washington: The Brookings Institution.

Jacob, Herbert. 1983. Justice in America. 4th ed. Boston: Little, Brown and Co. Ch. 2. . 1968. The Effect of Institutional Differences in the Recruitment Process. Journal of Public Law 13:104.

Johnson, Charles and Canon, Bradley. 1984. Judicial Policies: Implementation and Impact. Washington, D.C.: Congressional Quarterly Press.

Lindblom, Charles E. 1968. The Policy-Making Process. Englewood Cliffs, N.J.: Prentice-Hall. Chs. 1-3, 13.

McDuff, Robert. 1989. The Voting Rights Act: The Plaintiffs' Perspective. Judicature 73:82.

National Center for State Courts. 1988. State Court Organization 1987. Williamsburg: NCSC.

Rosenberg, Maurice. 1966. The Qualities of Justices: Are They Strainable? Texas Law Review 44:1063.

Schubert, Glendon. 1974. Judicial Policy Making. Glenview Ill.: Scott, Foresman and Co.

Tarr, G. Alan. 1977. Judicial Impact and State Supreme Courts. Lexington, Mass.: Lexington Books. 


\section{James D. Gingerich}

Wasby, Stephen. 1970. The Impact of the U.S. Supreme Court: Some Perspectives. Homewood, Ill.: The Dorsey Press.

Watson, Richard and Downing, Rondal. 1969. The Politics of the Bench and the Bar. New York: John Wiley and Sons, Inc. 